\title{
PENGARUH PENGETAHUAN AKUNTANSI DAN SKALA USAHA TERHADAP PENGGUNAAN INFORMASI AKUNTANSI PADA USAHA KECIL MENENGAH (UKM) DI KABUPATEN KUNINGAN
}

\author{
Enung Nurhayati \\ Universitas Kuningan \\ (enung21@yahoo.co.id) \\ Lia Dwi Martika \\ Universitas Kuningan \\ (enung21@yahoo.co.id)
}

\begin{abstract}
ABSTRAK
Penelitian ini bertujuan untuk mengetahui pengaruh pengetahuan akuntansi dan skala usaha terhadap penggunaan informasi akutansi pada Usaha Kecil Menengah (UKM) di Kabupaten Kuningan.

Metode pengumpulan data yang digunakan dalam penelitian ini adalah dengan metode survey lapangan dengan menebar kuisioner dan wawancara langsung terhadap narasumber. Pengujian terhadap kevalidan dan keandalan data dilakukan untuk kemudian dilakukan pengujian analisis. Pengujian koefisien determinasi, Uji t serta Uji F dilakukan untuk pembuktian hipotesis.

Hasil dari penelitian ini adalah secara parsial pengetahuan akuntansi dan skala usaha berpengaruh positif terhadap penggunaan Informasi Akuntansi, sedangkan secara simultan pengetahuan akuntansi dan skala usaha berpengaruh secara positif terhadap penggunaan informasi akuntansi.

Kata kunci : pengetahuan akuntansi, skala usaha, informasi akuntansi.

\section{Pendahuluan}

Usaha Kecil dan Menengah atau yang dikenal UKM memiliki peranan yang sangat penting di dalam perekonomian Indonesia. Peran utama dari UKM adalah dapat menyerap banyak tenaga kerja sehingga mengurangi jumlah pengangguran dan tingkat kemiskinan di dalam negeri. Peran lainnya yang juga sering disebut adalah bahwa UKM yang telah go international dapat memberikan sumbangan dalam menjaga neraca pembayaran melalui sumbangannya dalam menghasilkan ekspor.

Dalam perjalanan perekonomian Indonesia sejak dilanda krisis ekonomi tahun 1997/1998 merupakan hal yang sangat menarik untuk melihat kekuatan UKM. Terbukti dengan banyaknya UKM yang cukup kuat menahan gejolak krisis ekonomi dan mampu melakukan penyesuaian segera untuk tetap mempertahankan kegiatan usahanya. Banyak UKM yang tetap memperoleh laba yang tinggi walaupun pada tahun 1998 selama puncak krisis pertumbuhan ekonomi yang negatif $13,4 \%$ mengakibatkan terjadinya penurunan
\end{abstract}


jumlah unit usaha sebanyak 2,95 juta unit lebih.

Permasalahan yang sering dihadapi oleh para pelaku bisnis UKM antara lain adalah mengenai pemasaran produk, teknologi, pengelolaan keuangan, kualitas sumber daya manusia, dan permodalan. Salah satu masalah yang seringkali terabaikan oleh para pelaku bisnis UKM yaitu mengenai pengelolaan keuangan. Dampak dari diabaikannya pengelolaan keuangan mungkin tidak terlihat terlalu jelas. Namun tanpa metode akuntansi yang efektif, usaha yang memiliki prospek untuk berhasil dapat menjadi bangkrut. Informasi yang dihasilkan oleh catatan-catatan akuntansi berguna bagi pengambilan keputusan usaha yang akan diambil oleh para pelaku bisnis UKM sehingga dapat meningkatkan pengelolaan perusahaan. Informasi-informasi tersebut memungkinkan para pelaku bisnis UKM untuk dapat mengidentifikasi dan memprediksi area-area permasalahan yang mungkin timbul kemudian mengambil keputusan yang tepat. Tanpa informasi akuntansi, masalah-masalah yang sekiranya dapat dihindari atau dipecahkan justru menjadi penyebab kebangkrutan usaha tersebut. Untuk itu penting sekali bagi para pelaku bisnis UKM untuk dapat membaca dan menafsirkan informasi akuntansi. Paling tidak setiap pelaku bisnis UKM dapat menghitung untung ruginya, akan tetapi yang paling penting untuk dapat memahami makna untung ataupun rugi bagi usahanya.

Adanya informasi akuntansi yang dihasilkan oleh catatan-catatan akuntansi dan diterapkan berdasarkan skala usaha dapat memaksimalkan informasi akuntansi itu untuk digunakan secara tepat dalam suatu pengambilan keputusan usaha. Penggunaan informasi akuntansi yang efektif tidak hanya dipengaruhi oleh pengetahuan yang cukup dari para pelaku bisnis UKM terhadap akuntansi tetapi juga skala usaha UKM tesebut, karena skala usaha UKM tersebut akan menunjukan seberapa besar kompleksitas perusahaan. Tingkat pengetahuan akuntansi ini dapat dilihat dari tingkat pengetahuan deklaratif dan pengetahuan prosedural para pelaku bisnis UKM.

Kepedulian

terhadap pengembangan UKM sudah semestinya menjadi tanggung jawab semua pihak sesuai dengan bidang yang digelutinya. Dalam penelititan ini, permasalahan yang dihadapi adalah sebagian besar pelaku bisnis UKM di Kabupaten Kuningan belum sepenuhnya menggunakan atau memahami informasi akuntansi dalam suatu pengambilan keputusan usaha.

\section{KERANGKA TEORITIS DAN HIPOTESIS}

\section{A. Kerangka Teoritis}

UKM merupakan jenis usaha kecil yang memiliki kekayaan bersih paling banyak Rp 200.000.000.- tidak termasuk tanah dan bangunan tempat usaha. Menurut Keputusan Presiden RI No. 99 tahun 1998, pengertian usaha kecil adalah "kegiatan ekonomi rakyat yang berskala kecil dengan bidang usaha yang secara mayoritas merupakan kegiatan usaha kecil dan perlu dilindungi untuk mencegah dari persaingan usaha yang tidak sehat."

Untuk dapat bersaing maka UKM harus dapat mengelola keuangannya dengan baik. Pengelolaan keuangan yang baik tidak terlepas dari penggunaan akuntansi. Menurut R.A. Supriyono (1993:18) definisi dari akuntansi adalah:

"Akuntansi adalah aktivitas yang menghasilkan jasa yaitu berfungsi 
menyajikan informasi kuantitatif yang pada dasarnya bersifat keuangan dari suatu satuan usaha atau organisasi tertentu. informasi tersebut akan dapat dipakai oleh pihak eksternal maupun pihak internal untuk pengambilan keputusan dengan memilih beberapa alternatif'.

Dari definisi tersebut menjelaskan tentang fungsi akuntansi sebagai sumber informasi keuangan yang dibutuhkan baik oleh pihak eksternal maupun pihak internal untuk suatu pengambilan keputusan.

Dalam suatu pengambilan keputusan usaha yang efektif diperlukan adanya informasi akuntansi yang dihasilkan oleh catatan-catatan akuntansi. Para pelaku bisnis UKM harus dapat membaca dan menafsirkan setiap informasi akuntansi yang dihasilkan agar informasi akuntansi yang digunakan didalam pengambilan keputusan usaha menjadi sangat tepat. Penggunaan informasi akuntansi yang tepat. juga dipengaruhi adanya pengetahuan atas akuntansi dari para pelaku bisnis UKM. Tanpa adanya pengetahuan yang memadai atas akuntansi maka akan sulit bagi para pelaku bisnis UKM dalam menggunakan informasi akuntansi sebagai dasar pengambilan keputusan yang efektif.

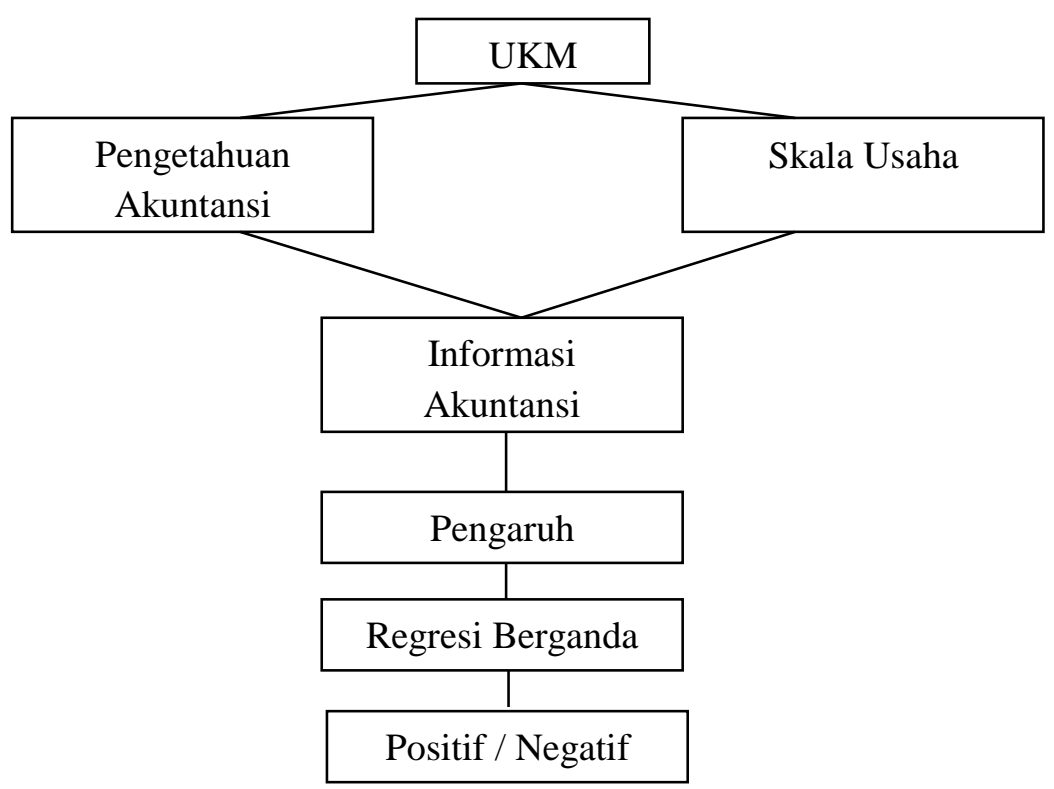

Gambar 1 Kerangka Pemikiran

\section{B. Hipotesis}

H1 : Pengetahuan akuntansi berpengaruh positif terhadap penggunaan informasi akuntansi.

H2 : Skala usaha berpengaruh positif terhadap penggunaan informasi akuntansi H3 : Pengetahuan akuntansi dan skala usaha berpengaruh positif terhadap penggunaan informasi akuntansi pada UKM di Kabupaten Kuningan.

\section{METODOLOGI}

\section{Metode Penelitian}

Populasi sasaran dalam penelitian ini adalah Jumlah Usaha Kecil Menengah 
(UKM) Kabupaten Kuningan yang sudah memiliki ijin (legal) berdasarkan data pada dari Badan Pelayanan Perizinan Terpadu (BPPT) Kabupaten Kuningan sampai tahun 2011 sebanyak 1.431 UKM yang terdiri dari UKM jenis industri, usaha perdagangan dan aneka usaha. Populasi yang dimaksud dalam penelitian ini adalah UKM yang telah memperoleh ijin (legal) di Kabupaten Kuningan. Sampel yang diambil dari populasi yang ada dilakukan secara Simple Random (acak), dengan menggunakan tingkat kesalahan 5\% dari daftar pengambilan sampel yang dianggap representative menurut Isaac dan Michael (Sugiono 2003:99). Pengambilan sampel dalam penelitian ini yang dianggap representative adalah UKM di Kabupaten Kuningan yang sudah memiliki legalitas usaha menurut Dinas Perindustrian dan Perdagangan Kabupaten Kuningan dan sudah menyusun laporan keuangan. Pada umumnya sudah ada catatan akuntansi namun hanya sederhana sebatas untuk pinjaman ke bank. Adapun sampelnya adalah sebesar $10 \%$ dari populasi yaitu sebanyak 143 UKM. Metode pengumpulan data penelitian adalah dengan survey lapangan, yaitu dengan menebar kuisioner dan wawancara. Dalam penelitian ini variabel bebasnya adalah "Pengetahuan Akuntansi (X1) dan Skala Usaha (X2)", sedangkan variabel terikatnya adalah "Penggunaan Informasi Akuntansi (Y)".

\section{Metode Analisis Data}

a. Uji Validitas dan Reliabilitas Instrumen

b. Analisis Deskriptif

c. Analisis Koefisien Determinasi

Untuk melihat seberapa besar variabel X1 (Pengetahuan Akuntansi) dan X2 (Skala Usaha) dapat memberikan pengaruh terhadap variabel Y (Penggunaan
Informasi Akuntansi), maka digunakan koefisisen determinasi (KD) yang merupakan kuadrat koefisien korelasi dan biasanya dinyatakan dalam \% dengan rumus sebagai berikut :

d.

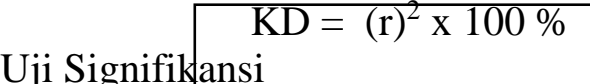

- Uji t

Uji signifikansi dilakukan untuk menguji hipotesis penelitian yang diajukan. Uji signifikansi dilakukan dengan menggunakan uji $\mathrm{t}$ dan uji $\mathrm{F}$. Penghitungan uji $t$ dapat dilakukan dengan menggunakan rumus sebagai berikut :

$$
\begin{aligned}
& \text { - Uji F } \\
& \text { Uji F Statistik digunakan untuk } \\
& \text { mengetahui tingkat signifikansi pada } \\
& \text { koefisien korelasi ganda: } \\
& \qquad F=\frac{R^{2}(N-M-1)}{M\left(1-R^{2}\right)}
\end{aligned}
$$

Nilai $F$ hasil perhitungan ini kemudian dibandingkan dengan $F_{\text {tabel }}$ yang diperoleh dengan menggunakan taraf nyata 0,05 .

\section{HASIL PENELITIAN DAN PEMBAHASAN}

Dari hasil perhitungan dan pengujian yang sebagaimana telah dilakukan, menunjukan bahwa terdapat pengaruh yang positif antara ketiga variabel (Pengetahuan Akuntansi, Skala Usaha dan Penggunaan Informasi Akuntansi). Disamping itu, persamaannya pun bersifat linier (searah). Hal ini menunjukan bahwa Penggunaan Informasi Akuntansi oleh pelaku Usaha Kecil Menengah (UKM) di Kabupaten Kuningan dipengaruhi oleh faktor Pengetahuan Akuntansi dan Skala Usaha secara signifikan dengan arah hubungan 
yang linier atau searah. Lebih lanjutnya hasil pengujian ini dapat diuraikan sebagai berikut :

a)

Pengaruh

Akuntansi

Penggunaan

Pengetahuan terhadap

Informasi

Akuntansi

Berdasarkan hasil analisis,

Pengetahuan Akuntansi yang dimiliki pelaku UKM mempunyai pengaruh yang positif terhadap Penggunaan Informasi Akuntansi dengan pengaruh sebesar 0,691 atau sebesar $69,1 \%$ (lampiran). Dengan demikian dapat dikatakan bahwa apabila pengetahuan akuntansi yang dimiliki oleh para pelaku UKM dapat ditingkatkan dan digunakan dengan baik, maka Penggunaan Informasi Akuntansi juga akan meningkat, dan sebaliknya, apabila pengetahuan akuntansi yang dimiliki oleh para pelaku UKM tidak dapat ditingkatkan dan digunakan dengan baik, maka Penggunaan Informasi Akuntansi sebagai dasar pengambilan keputusan juga akan rendah.

Hasil penelitian tersebut searah dengan hasil penelitian Suhairi, Yahya dan Haron pada tahun 2004, yang meneliti hubungan pengetahuan akuntansi dan kepribadian wirausaha terhadap penggunaan informasi akuntansi. Hasil penelitian menunjukkan bahwa pengetahuan akuntansi seorang wirausaha mempunyai pengaruh positif terhadap penggunaan informasi akuntansi.

Dalam suatu proses pengambilan keputusan usaha yang efektif diperlukan banyak faktor yang harus dipertimbangkan. Terutama keputusan usaha yang berhubungan dengan kebijakan keuangan perusahaan tentu memerlukan adanya informasi akuntansi yang dihasilkan oleh catatan-catatan akuntansi sebagai bahan pengambilan keputusan yang efektif. Adanya proses penafsiran informasi akuntansi yang ada, akan sangat mempengaruhi keefektifan pengambilan keputusan usaha. Oleh karena itu, diperlukan kompetensi dan kemampuan memadai yang harus dimiliki oleh pelaku usaha dalam hal ini pemilik usaha atau manajer yang senantiasa melakukan proses pengambilan keputusan. Kemampuan utama yang perlu dimiliki tentu terkait dengan kemampuan menafsirkan informasi, khususnya informasi akuntansi dengan baik sehingga menghasilkan keputusan yang efektif. Kemampuan tersebut dapat dinilai dari seberapa besar pengetahuan akuntansi, dalam hal ini mencakup pengetahuan deklaratif dan pengetahuan prosedural yang dimiliki oleh pemilik usaha atau manajer yang senantiasa melakukan proses pengambilan keputusan.

Sehingga para pelaku UKM, dalam hal ini pemilik usaha atau manajer yang senantiasa melakukan proses pengambilan keputusan, harus dapat membaca dan menafsirkan setiap informasi akuntansi yang dihasilkan agar informasi akuntansi yang digunakan didalam pengambilan keputusan usaha menjadi sangat tepat. Dimana kemampuan membaca dan menafsirkan informasi akuntansi tersebut akan sangat dipengaruhi oleh pengetahuan akuntansi yang dimiliki.

b) Pengaruh Skala Usaha terhadap Penggunaan Informasi Akuntansi

Berdasarkan hasil analisis, Skala Usaha Usaha Kecil Menengah (UKM) mempunyai pengaruh yang positif terhadap Penggunaan Informasi Akuntansi dengan pengaruh sebesar 0,203 atau sebesar 20,3\% (lampiran). Dengan demikian dapat dikatakan bahwa skala usaha akan mempengaruhi dalam penggunaan informasi akuntansi dalam 
pengambilan keputusan pada UKM di Kabupaten Kuningan.

Skala usaha menunjukkan kemampuan sebuah UKM dalam mengelola usahanya dengan melihat berapa banyak jumlah karyawan yang dipekerjakan pada UKM tersebut dan berapa besar pendapatan yang diperoleh UKM dalam satu periode akuntansi. Sehingga dalam usaha untuk memperoleh hasil yang maksimal bagi UKM, para pelaku UKM harus mempertimbangkan jumlah karyawan yang dipekerjakan dan bagaimana mengelola usaha agar pendapatan yang diperoleh UKM dapat maksimal.

Jumlah karyawan pada suatu usaha dapat menunjukkan seberapa efektif perusahaan memperoleh pendapatan. Dengan jumlah karyawan yang proporsional dalam lingkup usaha UKM tersebut, maka akan mendorong efisiensi biaya sehingga pencapaian hasil usaha akan lebih maksimal. Penggunaan informasi akuntansi akan dipengaruhi oleh jumlah karyawan karena menunjukkan bagaimana sebuah informasi akuntansi yang ada, digunakan dalam keputusan dengan mempertimbangkan jumlah karyawan yang ada dalam perusahaan terseut, dalam hal ini UKM. Sebab sebuah keputusan usaha yang menyangkut UKM tentu diambil dengan mempertimbangkan dampaknya terhadap karyawan pada UKM tersebut dan bagaimana efektifitas sebuah keputusan itu terlihat dari penerapannya oleh karyawan yang ada di dalamnya.

Sehingga jumlah karyawan dapat menunjukkan berapa kapasitas perusahaan dalam mengoperasionalkan usahanya. Semakin besar jumlah karyawan semakin besar tingkat kompleksitas perusahaan, sehingga informasi akuntansi sangat dibutuhkan.

Selain jumlah karyawan, skala usaha juga ditentukan dengan seberapa besar jumlah pendapatan atau penjualan yang dihasilkan perusahaan. Sebab jumlah pendapatan dapat menunjukkan perputaran asset atau modal yang dimiliki oleh perusahaan. Sehingga semakin besar pendapatan atau penjualan yang diperoleh perusahaan semakin besar pula tingkat kompleksitas perusahaan dalam menggunakan informasi akuntansi.

Oleh karena itu, dalam penggunaan informasi akuntansi sebagai dasar pengambilan keputusan untuk UKM akan dipengaruhi oleh skala usaha UKM tersebut. Skala usaha ini terlihat dari berapa banyak karyawan yang diperkerjakan dan seberapa besar pendapatan yang diperoleh UKM tersebut.

\section{SIMPULAN DAN IMPLIKASI PENELITIAN}

Dari hasil penelitian yang telah dilakukan oleh penulis, dapat diambil kesimpulan bahwa pengetahuan akuntansi berpengaruh secara positif terhadap penggunaan informasi akuntansi, skala usaha berpengaruh secara positif terhadap penggunaan informasi akuntansi, pengetahuan akuntansi dan skala usaha berpengaruh secara positif terhadap penggunaan informasi akuntansi.

Berdasarkan penelitian ini para pemilik atau manajer Usaha Kecil Menengah (UKM) diharapkan dapat lebih meningkatkan kemampuan dan pengetahuan di bidang akuntansi. Sebab sebagai pengambil keputusan atau kebijakan pada UKM, pengetahuan akuntansi diperlukan untuk dapat menghasilkan keputusan yang baik. Sehingga diperlukan kemampuan 
terutama dalam pengetahuan akuntansi yang cukup memadai untuk bisa menggunakan informasi akuntansi yang ada sebagai dasar pengambilan keputusan yang tepat untuk UKM.

Selain itu para pemilik atau manajer Usaha Kecil Menengah (UKM) diharapkan dapat lebih meningkatkan skala usaha, dengan cara memperhitungkan komposisi dan biaya untuk karyawan yang sesuai dengan kebutuhan dan kapasitas usaha UKM. Selain itu, peningkatan pendapatan UKM juga harus diikuti dengan pengelolaan yang semakin baik. Sehingga, ketika terjadi peningkatan skala usaha, proses pengambilan keputusan yang semakin kompleks akan dapat diatasi dengan baik melalui pemahaman menyeluruh mengenai komponen skala usaha.

Terakhir, para pemilik atau manajer Usaha Kecil Menengah (UKM) diharapkan dapat lebih memksimalkan pengambilan keputusan dengan menggunakan informasi akuntansi yang telah dihasilkan, diantaranya dengan menginterpretasikan laporan keuangan dengan sangat baik. Sehingga dengan menggunakan informasi akuntansi yang ada, pengambilan keputusan dapat lebih kuat dengan didasari informasi yang sesuai.

\section{DAFTAR PUSTAKA}

A. Hall. James. 2001. Sistem Informasi Akuntansi. Jakarta : Salemba Empat.

Mulyadi. 1993. Akuntansi Manajemen.

Rudianto. 2009. Pengantar Akuntansi. Jakarta : Erlangga.

Sofyan Syafri Harahap. 2005. Teori Akuntansi. PT RajaGrafindo Perkasa : Jakarta.

Sugiyono. 2011. Metode Penelitian Bisnis. Bandung : CV Alfabeta.

Williams. Chuck. 2001. Manajemen. Jakarta : Salemba Empat.

Winarno. Wing Wahyu. 2002. Sistem Informasi Akuntansi. Yogyakarta : UPP STIM YKPN.

http://claraalverna.blogspot.com/2011/11/ proses-terbentuknya-ukm.html 